\title{
Weeds and Weed Control Methods in Sudan
}

\author{
Azhari Abdelazim Hamada \\ Agricultural Research Corporation, Wad Medani, Sudan; \\ Present address, Center for Research on Wild Plants, \\ Utsunomiya University, 350 Mine-machi, Utsunomiya 321-8505, \\ Japan
}

Weeds are one of the major components of the ecosystem. They comprise an essential vegetation cover to protect the soil from wind and running water erosion (Table 1). In Sudan there is more than 80 million ha suitable for growing crops, but only $12 \%$ is utilized. The principal crops are sorghum, cotton, groundnut, millet, wheat, sugar cane and vegetables. Weeds are the major constraint to crop production in all cultivated areas in Sudan. Unrestricted weed growth promotes soil degradation in cultivated lands and reduces yield of the main crops by 50-100\% (Table 2). Striga hermonthica and Orobanche ramose are the most important parasitic weeds on cereals and vegetables, respectively. Losses in grain yield of sorghum (Sorghum bicolor) and millet (Penisetum glucum) due to Striga hermonthica damage are more than $\mathbf{7 0} \%$ in heavily infested fields. $O$. ramose threatens tomato and egg plants main production areas in the northern region and along the Nile bank. Aquatic weeds, on the other hand, reduce the efficiency of irrigation canals by hindering water flow and encouraging siltation. The efficacy of the main canal in Rahad Agricultural Scheme has been reduced from 8.5 to 5.5 million $\mathrm{m}^{3}$ of water per day. Many weeds have been reported as alternate hosts for some economically important pests and as poisonous plants to man and animals. A negative allelopathic potential has associated with a number of weeds including Cyperus rotundus and Cynodon dactylon. Cultural and chemical methods of weed control are in use (Table 3). However the decision to adopt a particular method is determined by socioeconomic factors. Weeds are not always harmful. Evidence has accumulated that some of the weed species such as Trifolium alexandrinum, Rhynchosia memonia, Phaseolus trilobus, Cassia senna and $C$. occidentalis induce suicidal germination of Striga hermonthica. This may lead to depletion of Striga hermonthica seed bank in the soil and consequently reduces the potential damage inflicted by the parasite. Weeds can also help in recycling soil nutrients and the beneficial effect of one season weedy fallow on the following crop was estimated by $45 \mathrm{Kg}$ N/ha. In addition, weeds are used as human food. In some parts of the country wild Okra, wild Jews mallow, Sonchus coruntus and wild purslane are used as major food sources. Moreover, some weed species such as Cassia senna and Colocynthis vulgaris are important in traditional medicinal.

Table 1. Runoff and erosion under various tillage treatments (from Young, 1982)

\begin{tabular}{llc}
\hline Tillage system & $\begin{array}{l}\text { Runoff } \\
\left(\mathrm{mm}=1 / \mathrm{m}^{2}\right)\end{array}$ & $\begin{array}{c}\text { Erosion } \\
\text { (tons/ha) }\end{array}$ \\
\hline No - tillage, dead sod on surface & 34 & 8.9 \\
No - tillage, bare soil surface & 73 & 21.8 \\
\hline
\end{tabular}


Table 2. Crop yield losses and the critical period of weed competition for some selected crops

\begin{tabular}{lccccc}
\hline & & \multicolumn{5}{c}{ Crop } \\
& Cotton & Groundnut & Sorghum & Onion & Coriander \\
\hline$\%$ Crop losses & $77-90$ & $80-100$ & $77-84$ & $50-73$ & $50-70$ \\
$\begin{array}{l}\text { Critical period of } \\
\text { Weed competition* }\end{array}$ & $4-(6-8)$ & $4-8$ & $3-(6-8)$ & $3-8$ & $2-5$ \\
\hline
\end{tabular}

\section{* Weeks after planting}

Table 3. Weed control methods in different crops and habitats

\section{Crop or habitat}

Cotton Groundnut Sorghum Millet Wheat Sugar cane Vegetables Rivers and

Weed control methods

\begin{tabular}{|c|c|c|c|c|c|c|c|c|}
\hline Hand weeding & +++ & +++ & +++ & +++ & + & ++ & +++ & ++ \\
\hline \multicolumn{9}{|l|}{ Herbicides } \\
\hline - Pre-em. & +++ & + & + & - & - & +++ & + & n.v \\
\hline - Post-em. & - & + & + & - & + & + & + & ++ \\
\hline \multicolumn{9}{|l|}{$\begin{array}{l}\text { Mechanical } \\
\text { weeding }\end{array}$} \\
\hline $\begin{array}{l}\text { - Heavy duty } \\
\text { - Inter raw }\end{array}$ & ++ & + & + & - & ++ & ++ & ++ & ++ \\
\hline $\begin{array}{l}\text { cultivator } \\
\text {-Pre-watering }\end{array}$ & ++ & + & - & - & - & + & - & n.v \\
\hline (or rain)+ Tillage & + & - & + & - & +++ & ++ & ++ & n.v \\
\hline Solarization & - & - & - & - & - & - & $-*$ & n.v \\
\hline $\begin{array}{l}\text { Biological } \\
\text { control }\end{array}$ & - & - & - & - & - & - & - & -* \\
\hline Sowing date & - & ++ & - & - & - & - & - & n.v \\
\hline Plant density & - & ++ & - & - & + & - & - & n.v \\
\hline Crop variety & - & - & + & - & - & - & - & n.v \\
\hline Crop rotation & - & - & + & - & - & - & - & n.v \\
\hline
\end{tabular}

Note: +++ intensively practiced; ++ moderately practiced; + occasionally practiced; - not practiced; $\therefore$ research in progress; n.v not valid 